\title{
Profit Loss Sharing System and Community Saving and Investment Scheme
}

\section{Syed Tahir Hijazi*}

Profit sharing refers to the splitting of profit between two or more business partners. It is a substitute to the interest system where one partner gets a fixed return irrespective of business performance. In the past two decades profit sharing has captured the attention of policy makers and researchers alike. This increased interest has been roused by factors including research interests in the West, practical supremacy of the system and commitment to Islam. Martin Wietzman $(1984,1987,1990)$ carried out research work on profit sharing, which gave respectability to the concept. Japan, during its boom era, used profit sharing in a small segment of the labour market. The UK passed legislation to provide tax incentives to encourage the adoption of profit - related pay schemes and following Islamic principles, a few Muslim economies attempted to modify banking practices in line with Islamic principles.

In the existing banking system based on the interest rate, the lender gets a fixed percentage of the return against the loaned amount, irrespective of the performance of business. The borrower is thus bound to pay a fixed percentage as a charge for using the fund. If he makes a higher profit percentage than the interest rate, he benefits more than the bank. If his profit is the same as the interest rate, the borrower is even. If the borrower makes a profit percentage less than the interest rate, he loses and has to pay the difference from his own pocket. If he is unable to pay the interest rate he may reschedule the loan and capitalise on the outstanding interest payment as loan. Thus the total interest he has to pay increases making it more difficult to survive. If loss or low profit persists the business often opts for bankruptcy. In a situation like that, both the bank and the owner of the business lose.

In today's banking world, interest base is the dominant lending system. The system has major problems. Adam Smith, who is considered the father of economics, was the first to introduce the interest rate system. He said, 'interest is a proxy for profit earned'. He also added that if we could use profit itself, as the guide for charging an interest rate, it is better. Probably economics had not developed as a subject at that stage to enable the devising of a system based on profit sharing. But today it is much easier to explore the possibility in the light of numerous problems attached to the

\footnotetext{
* The author is Associate Dean, Muhammad Ali Jinnah University Karachi, Islamabad Campus.
} 
interest rate. The interest based loaning system has several problems. Broadly these could be divided into problems at the macro and micro level.

\section{Macro Level Problems}

When the economy is booming, business expands faster than banks as the profit margins are higher than the interest rate. The income of depositors does not expand at the same rate as business because of the fixed rate of interest. Their purchasing power thus does not expand at the rate of economic expansion. Demand lags behind supply leading to recession. During a recession business is unable to pay the interest rate as the profit margin falls below the interest rate leading to excess production and inventory builds up culminating in recession. Alternatively during recession some businesses are unable to pay back interest and the principle, some of the banks focus on a number of defaulters and declare bankruptcy, and depositors lose their savings. Purchasing power further falls and recession is intensified.

\section{Micro Level Problems}

At the micro level, a fixed interest rate creates even greater damage. New businesses are the major affectees of the interest system. Smaller businesses in particular and medium and larger businesses in general are unable to make sizable profit margins in the beginning. If they are unable to pay interest they may have to pay a bigger interest rate in the following years over the capitalised interest or compounded interest rate. This increased financial cost often results in failure of the firm to survive. Problems at the macro and micro level necessitate a look into alternative systems of financing. Profit sharing provides that alternative.

\section{Structure of Profit Sharing System}

A profit sharing system requires an advance agreement between borrower and lender to share profit in the ratio of 50:50, 40:60 or in any other combination. If business makes a loss then both are supposed to share the loss. The theme of the system requires businesses to survive to their maximum and may not close due to unforeseen variation in the market. Monitoring of the profit sharing system is higher than interest based financing and it is as practicable as the interest based financing system.

\section{Community Saving and Investment Needs}

Micro businesses and cottage industry often provide a wide range of job opportunities, therefore economic planners are often more interested in developing this sector. But banks are often reluctant to extend micro credit because of the high operation cost of lending. Governments in general have 
failed to run micro credit schemes both because of the high cost of operations and because of an inefficient monitoring system. Community and small investors are pushed away from the government and banks because of a number of problems, including the following:

$\theta \quad$ Too much paper work

$\theta \quad$ Lack of understanding of procedures

$\theta$ Low literacy rate

$\theta$ Shyness

$\theta \quad$ Higher interest rate to pay

$\theta \quad$ Limited access to banks

An alternative to this is community saving and investment scheme.

\section{Community Saving and Investment Scheme (CSIS)}

\section{Objectives}

The objective of CSIS is to increase the income of individuals in the community through micro-business schemes.

\section{Methodology}

In this model the community is organised into a group or organisation which collects savings from the community on a monthly basis. These are entered into a register with the name of the depositor and date of deposit. At regular monthly meetings the community organisation (CO) decides on the recipient of the loan in that month. CO assesses the potential of business and lends to small entrepreneurs on the basis of his/her profit potential. Initially, the size of a single loan is supposed to remain below Rs. 5,000/-.This may be increased depending on the availability of funds and the potential of the lender to utilise it profitably. As a rule of thumb no individual investment loan should increase above 5 per cent of the community's total saving.

\section{Monitoring}

Since the return on investment is to be determined on the basis of actual profit made, two representatives of the community are associated with each investor to monitor his performance. They will enter total cost incurred, the sale receipts and the calculated profit of the day. The register used for the purpose will be the total account of the month. The manager and monitors of funds are paid a monthly salary as a percentage of the total monthly profit of the community. 


\section{Profit Calculation}

There are two types of profits to be calculated, first the amount to be charged to business and second, the amount which is available for distribution to the savers.

\section{Charge to investor/borrower}

The borrower is supposed to return the loan as well as a margin of the profit earned over his investment. If the profit loss sharing is fixed as 50:50 he has to pay half the profit or share losses with the community. So his monthly return to the community will be based on the following formula:

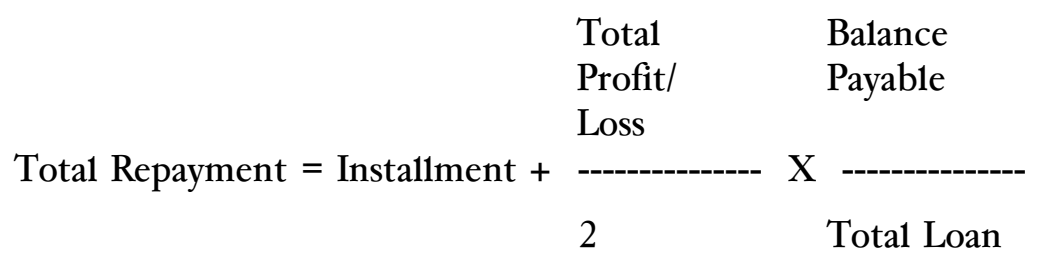

\section{Requirements of the Scheme}

To calculate profit accurately the following costs must be included:

- labour charges of the lender

- rent of the place

- cost of all type of raw material

- Any cost incurred on sales promotion, advertisement etc.

Training needs;

The community needs to be trained in book keeping, profit measurement, profit calculation, monitoring and assessment of the potential of businesses. Furthermore the community is required to be properly organised.

\section{Advantages of this Scheme over other Schemes}

- There is flexibility of the amount to be invested 
- Community is involved in the business activities of individual borrower, developing a community spirit and learning process for others.

- Declaration of profits makes every thing transparent. It reduces the risk of default and a source of expanding knowledge of the business.

- Since every one benefits in high profit schemes there will be a strong tendency to lend to a business that has higher expected profit margin over and above political influence.

\section{Benefit to Savers}

Savers are eligible to draw profits from the scheme. An individual contributing his fund will be able to draw profit from the scheme at almost the same level as the borrower/investor. The total profit calculated at the end of each month could be redistributed to the savers or is reinvested on behalf of the savers. What ever may be the situation the profit calculated will go to the accounts of each individual who has invested according to his share.

A widow, orphan and handicapped person who cannot start a business of his/her own, can invest their savings through the community. Savers and contributors of funds can draw profits every month or provide the permission to reinvest their profits as investment. The saver's share of profit to be calculated using the following formula:

$$
\begin{aligned}
\text { Depositor's Profit }= & \begin{array}{l}
\text { Saver's contribution } \mathrm{X} \text { Total Profit } / 2 \mathrm{X} \text { Total } \\
\text { Community saving }
\end{array}
\end{aligned}
$$

\section{Administering Cost of Borrowing \& Lending}

The administrative cost of running CSIS needs to be deducted before the profit is distributed to savers (contributor) of funds. The cost should include stationary cost, photocopying cost and an honoraria for the funds manager and funds monitoring staff. Honoraria must be a percentage of the monthly profit of the community. 
116 The Lahore Journal of Economics, Vol.4, No.2

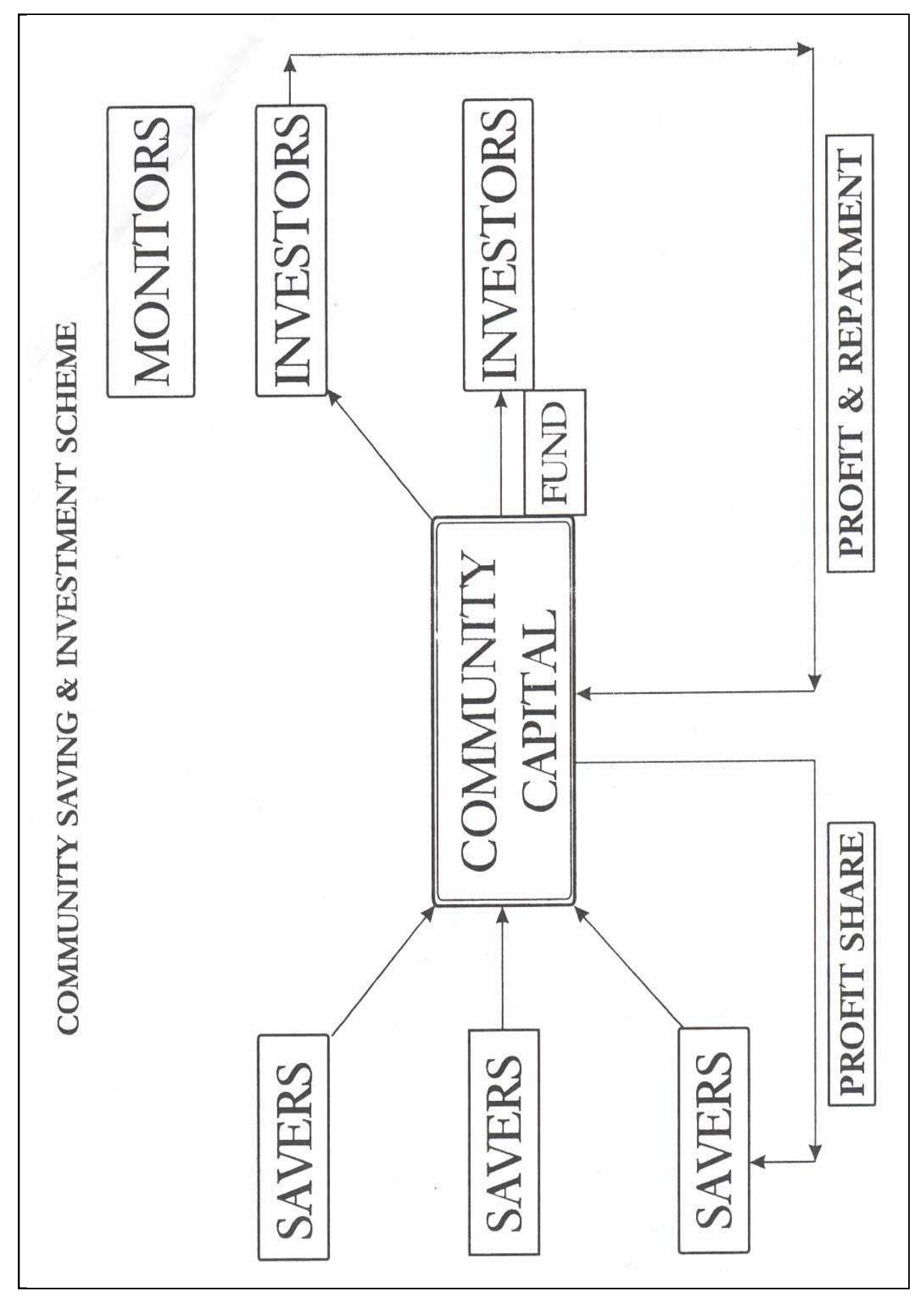


Syed Tahir Hijazi 117

\section{Advantages of this Scheme over other Schemes}

There is flexibility of the amount to be invested

Community is involved in the business activities of individual borrower, developing a community spirit and learning process for others.

Declaration of profit makes every thing transparent. It reduces the risk of default and is a source of expanding knowledge of the business.

Since every one benefits in high profit schemes there will be a strong tendency to lend to a business that has higher expected profit margin over and above political influence.

\section{Benefit to Savers}

Savers are eligible to draw profits from the scheme. An individual contributing his fund will be able to draw profit from the scheme at the same level as the borrower/investor. The total profit calculated at the end of each month could be redistributed to the savers or reinvested on behalf of savers. What ever may be the situation the profit calculated would go to the accounts of each individual who has invested according to his share.

A widow who can not start a business of her own can invest her savings through the community. Savers and contributors of funds could draw profit monthly or provide the permission to reinvest their profit as investment. The saver's share of profit to be calculated using the following formula:

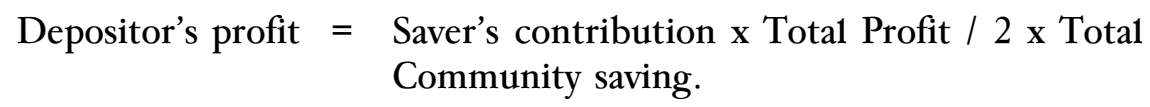

\section{Administering cost of Borrowing \& Lending}

The administrative cost of running CSIS needs to be deducted before the profit is distributed to savers (contributors) of funds. The cost should include stationary cost. Photocopy cost and honoraria for the one who is keeping the accounts and monitoring them. Honoraria must be a percentage of monthly profit of the community. 
118 The Lahore Journal of Economics, Vol.4, No.2

\section{References}

Hijazi S.T. and Amanullah M.K., 1997, "Profit Sharing” Melmillan Publishers Lahore.

Usmani. M. Taqi, 1988, “An Introduction to Islamic Finance" Idaratual Ma'arif, Karachi, Pakistan.

Bashir, Abdel-Hameed Mohammad, 1990, "Financial Contracts in InterestFree Islamic Economics: Theory and Practice", The University of Wisconsin - Madison (0262), Ph.D. thesis, p 133.

Beason, Richard Derek, 1989, "Microfoundations of the Japanese Macroeconomy: An Empirical Study", The University of Michigan (0127), Ph.D. thesis, p 193.

Weitzman L. Martin, 1987, 'Steady State Unemployment Under ProfitSharing', Economic Journal 97, pp 86-105.

Weitzman L. Martin, 1985, 'The Simple Macroeconomics of Profit-Sharing', The American Economic Review, Vo1 75, pp 937-53. 